\title{
Association of the XRCC1 gene polymorphisms with cancer risk in Turkish breast cancer patients
}

\author{
Ugur Deligezer ${ }^{1}$ and Nejat Dalay ${ }^{1,2}$ \\ ${ }^{1}$ Department of Basic Oncology \\ Oncology Institute Istanbul University \\ Istanbul, Turkey \\ ${ }^{2}$ Corresponding author: Tel, 90-212-5313100; \\ Fax, 90-212-5348078; E-mail, ndalay@yahoo.com
}

Accepted 9 December 2004

Abbreviations: BRCA1, Breast cancer-associated gene 1; BRCT-1, BRCA1 C terminus repeat $1 ; \mathrm{Cl}$, Confidence interval; OR, Odds ratio; XRCC1, X-ray repair cross-complementing group 1

\begin{abstract}
The $X$-ray repair cross-complementing group 1 (XRCC1) gene is believed to play an important role in base excision repair and displays genetic polymorphisms. Data on the role of XRCC1 polymorphisms in cancer susceptibility is inconsistent. In the present study, we investigated the effect of two XRCC1 polymorphisms, Arg194Trp and Arg399GIn, on breast cancer risk in a casecontrol study involving Turkish breast cancer patients and healthy women. Both alleles exhibited a similar distribution among cases and controls leading to lack of any significant association between the XRCC1 polymorphisms and breast cancer risk, either in homozygotes and heterozygotes or combined. The allele frequency of the codon 194 variant was very low in cases and healthy individuals (5.3 and $3.9 \%$, respectively) compared to that of the variant $399 \mathrm{GIn}$ allele $(39.7$ and $37.4 \%$ ). Our results do not support evidence for a role of the XRCC1 polymorphism in developing breast cancer.
\end{abstract}

Keywords: breast cancer; risk; polymorphism; XRCC1

\section{Introduction}

Breast cancer is the most prevalent common malignancy among women and the incidence is still increasing. A substantial fraction of breast cancer cases is explained by well-established risk factors such as the age at the first child's birth, nulliparity and family history (Madigan et al., 1995). In the majority of cases the cause of the disease is still obscure. Amino acid substitutions in the DNA repair genes as result of genetic polymorphisms may lead to alterations in DNA repair capacity and affect the susceptibility to cancer. Polymorphic alleles have been described for many DNA repair genes including the genes responsible for nucleotide and base excision repair (Shen et al., 1998; Fan et al., 1999). Recent data suggest that DNA repair capacity may vary between individuals (Berwick, 2000) and is lower in cancer patients than healthy controls (Mohrenweiser and Jones, 1998). It has been hypothesized that multiple alleles may act in combination in conferring cancer risk (Mohrenweiser and Jones, 1998; Shen et al., 1998).

The protein encoded by the XRCC1 gene plays an important role in base excision repair and removes base adducts formed by ionizing radiation and alkylating agents (Yu et al., 1999). The multi-domain protein interacts with DNA ligase III, DNA polymerase $\beta$ and poly (ADP-ribose) polymerase in the base excision repair pathway (Kubota et al., 1996; Nash et al., 1997; Masson et al., 1998; Vidal et al., 2001). It contains a BRCT-1 domain bearing homology to $B R C A 1$ through which it interacts with DNA ligase III (Kubota et al., 1996) and poly (ADP-ribose) polymerase (Masson et al., 1998). Three polymorphisms (Arg194Trp, Arg280His and Arg399GIn) in the XRCC1 gene have been described (Mohrenweiser and Jones, 1998). The Arg399GIn polymorphism occurs within the BRCT-1 domain while the Arg194Trp leads to an amino acid substitution in the hydrophobic region of the protein. Since amino acid substitutions in the active sites may result in reduced efficiency to repair DNA damage these polymorphisms may confer increased risk to breast cancer. Concordantly, the codon 399 polymorphism has been shown to affect DNA repair capacity (Lunn et al., 1999), while the significance of the other two polymorphisms is not yet known.

Previous studies investigating the association between genetic polymorphisms and risk of different cancer types have provided inconsistent results (Ratnasinghe et al., 2001; Stern et al., 2001; Nelson et al., 2002). Data from studies investigating the association of the XRCC1 polymorphisms with breast cancer risk are also inconsistent (Duell et al., 2001; Kim et al., 2002; Moullan et al., 2003; Shu et al., 2003; Smith et al., 2003a; b). In the present study, we investigated the effect of two polymorphisms in the XRCC1 gene on breast cancer risk in a Turkish breast cancer population. 


\section{Materials and Methods}

Our study group consisted of breast cancer patients with similar ethnical background ( $n=151$; mean age $51.5 \pm 11.2$; age range $29-75$ ) regardless of menopausal status and family history to evaluate the general cancer risk in unselected cases. Control samples were taken from 133 healthy women (mean age $41 \pm 11.3$; age range 23-70). Genomic DNA was prepared from blood lymphocytes according to the standard protocol.

Genotyping of the XRCC1 polymorphisms was performed by a multiplex PCR. The reaction mixture contained $2.5 \mu \mathrm{l} 10 \mathrm{X}$ reaction buffer, $2.5 \mathrm{mM} \mathrm{MgCl}$, $200 \mu \mathrm{M}$ dNTPs, $0.6 \mu \mathrm{M}$ of each primer, $0.5 \mu \mathrm{g}$ DNA and $2.0 \mathrm{U}$ of Taq polymerase (Promega, Madison) in a total volume of $25 \mu \mathrm{l}$. Primers (Integrated DNA Technologies, Coralville, IA) used were; for codon 194: 5'-GCCCCGTCCCAGGTA-3' (forward) and 5'AGCCCCAAGACCCTTTCACT-3' (reverse) and for codon 399: 5'-TTGTGCTTTCTCTGTGTCCA-3' (forward) and 5 '-TCCTCCAGCCTTTTCTGATA-3' (reverse). The initial denaturation of $5 \mathrm{~min}$ at $95^{\circ} \mathrm{C}$ was followed by 35 cycles of amplification beginning with a denaturation step of $30 \mathrm{~s}$ at $95^{\circ} \mathrm{C}$, annealing for $1 \mathrm{~min}$ at $62^{\circ} \mathrm{C}$ and extension for $45 \mathrm{~s}$ at $72^{\circ} \mathrm{C}$. The reaction was completed by a final extension for $5 \mathrm{~min}$ at $72^{\circ} \mathrm{C}$. The products (491 bp and $615 \mathrm{bp}$ for codons 194 and 399 , respectively) were resolved on a $1.5 \%$ agarose gel containing $5 \mu \mathrm{g} / \mathrm{ml}$ ethidium bromide and visualized under UV-light.

Enzyme digestions of the PCR products were performed in a final volume of $20 \mu \mathrm{l}$ at $37^{\circ} \mathrm{C}$ for $16 \mathrm{~h}$ using $5 \mathrm{U}$ of Hpall (Promega, Madison). The fragments were separated on $1.5 \%$ agarose gels containing ethidium bromide and evaluated using a video gel documentation system (Vilber-Lourmat, Cedex, France).

The enzyme Hpall recognizes the wild-type alleles of codons 194 and 399 . It has two recognition sites on the $491 \mathrm{bp}$ fragment at the positions 174 and 198 of which the position 198 is the polymorphic site. Thus, the wild-type allele of codon 194 generates three fragments of 292, 174 and $24 \mathrm{bp}$, while the variant allele leads to two fragments of 318 and 174 $\mathrm{bp}$. The $174 \mathrm{bp}$ fragment from the digestion of the $491 \mathrm{bp}$ fragment is always present irrespective of the genotype and was used as an internal control for complete digestion.

The enzyme has a single recognition site on the $615 \mathrm{bp}$ fragment. The wild-type allele results in two fragments of 374 and $241 \mathrm{bp}$; the variant allele is present as an undigested $615 \mathrm{bp}$ fragment.

Statistical analyses were performed using the statistical package Instat ${ }^{+}$for Windows (Statistical Services Centre; University of Reading, Reading, UK). Odds ratios (ORs) and 95\% confidence intervals were calculated.

\section{Results and Discussion}

Genetic polymorphisms in the DNA repair genes may impair their function and enhance cancer susceptibility. The effect of XRCC1 gene polymorphisms on cancer susceptibility is still not clear and the results up to now are inconsistent (Ratnasinghe et al., 2001; Stern et al., 2001; Nelson et al., 2002). Studies investigating the association between polymorphisms and breast cancer risk have also led to contradictory results. An association between the $399 \mathrm{GIn}$ allele and breast cancer risk among African-American (Duell et al., 2001) and Asian women (Kim et al., 2002) has been suggested by two studies. On the other hand, in a more recent report (Smith et al., 2003a) a weak association for the 194Trp allele, but not for the $399 \mathrm{GIn}$ allele was observed in Caucasian women. There are also studies in the literature reporting lack of association between the breast cancer risk and $194 \mathrm{Trp}$ and/or the $399 \mathrm{GIn}$ polymorphisms in Chinese and French breast cancer patients (Moullan et al., 2003; Shu et al., 2003). These results suggest that the risk conferred by XRCC1 may vary between ethnic groups.

In this study we investigated the association between the two XRCC1 polymorphisms and breast cancer risk in a homogenous breast cancer population. The frequency of the genotypes was evaluated in breast cancer patients and healthy controls. Figure 1 shows a representative gel for the Arg194Trp and Arg399GIn polymorphisms. The allele frequencies in the healthy controls were consistent with those predicted from the Hardy-Weinberg equilibrium (Table I).

The variant $399 \mathrm{GIn}$ allele is much more common than the variant 194Trp allele in both groups. On the other hand, the allele frequency of the codon 194

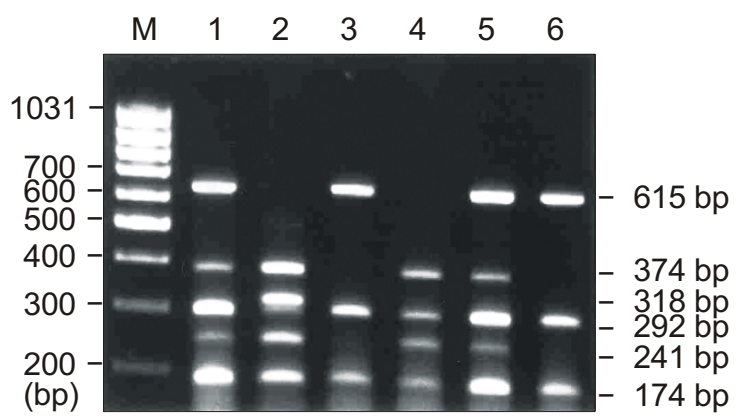

Figure 1. XRCC1 gene polymorphisms in breast cancer patients. Polymorphic regions of the codons 194 and 399 were amplified by a multiplex PCR, the products were digested with Hpall and separated by gel electrophoresis. Lanes 1 and 5 demonstrate patients with Arg194Arg and Arg399GIn genotypes. Lane 2: Arg194Trp and Arg399Arg; Lanes 3 and 6: Arg194Arg and Gln399GIn; Lane 4: Arg194Arg and Arg399Arg. $M$ is the DNA size marker with indicated fragment sizes left (bp, base pairs). 
Table 1. XRCC1 genotypes and allele frequencies in the patients and controls.

\begin{tabular}{|c|c|c|c|c|c|c|}
\hline XRCC1 194 & $\mathrm{~N}$ & Arg/Arg & Arg/Trp & Trp/Trp & $\begin{array}{l}\text { Arg/Trp- } \\
\text { Trp/Trp }\end{array}$ & $\begin{array}{l}194 \operatorname{Trp} \\
\text { frequency }\end{array}$ \\
\hline Controls & 133 & $119(89.5 \%)$ & $14(10.5 \%)$ & $0(0.0 \%)$ & $14(10.5 \%)$ & 0.053 \\
\hline Breast cancer & 151 & $\begin{array}{c}143(94.7 \%) \\
\text { (Reference) }\end{array}$ & $\begin{array}{c}7 \quad(4.6 \%) \\
P=0.099 \\
\text { OR }=0.416 \\
95 \% \mathrm{Cl}: \\
0.163-1.064\end{array}$ & $1(0.7 \%)$ & $\begin{array}{c}8(5.3 \%) \\
P=0.155 \\
\text { OR }=0.475 \\
95 \% \quad C l: \\
0.193-1.172\end{array}$ & 0.039 \\
\hline XRCC1 399 & $\mathrm{~N}$ & Arg/Arg & $\operatorname{Arg} / G \ln$ & $\mathrm{G} \ln / \mathrm{G} \ln$ & $\begin{array}{l}\mathrm{Arg} / \mathrm{G} \ln - \\
\mathrm{G} \ln / \mathrm{G} \ln \end{array}$ & $\begin{array}{l}\text { 399GIn } \\
\text { frequency }\end{array}$ \\
\hline Controls & 133 & $50(37.6 \%)$ & $66(49.6 \%)$ & $17(12.8 \%)$ & $83(62.4 \%)$ & 0.374 \\
\hline Breast cancer & 151 & $\begin{array}{l}58(38.5 \%) \\
\text { (Reference) }\end{array}$ & $\begin{array}{c}68 \quad(45.0 \%) \\
P=0.742 \\
\text { OR }=0.889 \\
95 \% \quad \mathrm{Cl}: \\
0.534-1.476\end{array}$ & $\begin{array}{c}25 \quad(16.5 \%) \\
P=0.645 \\
\text { OR }=1.2677 \\
95 \% \quad \mathrm{Cl}: \\
0.615-2.61\end{array}$ & $\begin{array}{c}93(61.5 \%) \\
P=1.0 \\
\text { OR }=0.966 \\
95 \% \quad \mathrm{Cl}: \\
0.598-1.56\end{array}$ & 0.397 \\
\hline
\end{tabular}

variant was very low in both groups. None of the controls and only one patient harbored the homozygoyte codon 194 variant. Distribution of both variant alleles was similar among the cases and the controls. The frequency of the variant $194 \mathrm{Trp}$ allele among the cases is slightly lower than that in healthy controls while the variant $399 \mathrm{GIn}$ allele frequency is slightly higher. Similar distribution of the variant alleles led to lack of any significant association between the $X R C C 1$ polymorphisms and breast cancer risk, either in homozygotes and heterozygotes or combined.

The very low frequency of codon 194Trp/Trp genotype in our patients is in accordance with data reported in Caucasian (0-2\%) and African-American (0\%) (Duell et al., 2001; Stern et al., 2001; Smith et al., 2003b) patients. The frequency of the codon $399 \mathrm{GIn} / \mathrm{Gln}$ genotype $(12 \%)$ is also consistent with the reports on Caucasians (13-16\%) (Duell et al., 2001; Stern et al., 2001; Nelson et al., 2002; Smith et al., $2003 b)$. On the other hand, the codon 194Trp/Trp frequency in the Turkish population is considerably lower than that in Asians (13\%) (Kim et al., 2002) while the codon $399 \mathrm{G} / \mathrm{n} / \mathrm{G} \ln$ frequency is much higher than that of both Asians and African-Americans (Duell et al., 2001; Stern et al., 2001; Kim et al., 2002).

Our results do not provide evidence for an association between the XRCC1 gene polymorphisms and breast cancer risk in the Turkish population. These data are in concordance with the subgroups in the previous studies. Lack of association between the $399 \mathrm{GIn}$ allele and breast cancer is in accordance with data on white American women, Chinese and French breast cancer patients (Duell et al., 2001; Moullan et al., 2003; Shu et al., 2003; Smith et al., 2003a) and lung cancer patients from China (Ratnasinghe et al., 2001). Lack of association between the 194Trp allele and breast cancer is also consistent with previous reports (Duell et al., 2001; Moullan et al., 2003). In conclusion, our study suggests that the XRCC1 gene does not provide a susceptibility marker for breast cancer.

\section{Acknowledgement}

This work was supported by the Istanbul University Research Fund (Project No: 50/23012003).

\section{References}

Berwick M. Gene-environment interaction in melanoma. Forum (Genova) 2000;10:191-200

Duell EJ, Millikan RC, Pittman GS, Winkel S, Lunn RM, Tse C-KJ, Eaton A, Mohrenweiser HW, Newman B, Bell DA. Polymorphisms in the DNA repair gene XRCC1 and breast cancer. Cancer Epidemiol Biomarkers Prev 2001;10:217-22

Fan F, Liu CP, Tavare S, Arnheim N. Polymorphisms in the human DNA repair gene XPF. Mutat Res 1999;406:115-20

Kim SU, Park SK, Yoo KY, Yoon KS, Choi JY, Seo JS, Park WY, Kim JH, Noh DY, Ahn SH, Choe KJ, Strickland PT, Hirvonen A, Kang D. XRCC1 genetic polymorphism and breast cancer risk. Pharmacogenetics 2002;12:335-8

Kubota Y, Nash RA, Klungland A, Schar P, Barnes DE, Lindahl T. Reconstitution of DNA base excision repair with purified human proteins: interaction between DNA polymerase beta and the XRCC1 protein. EMBO J 1996;15:6662-70 
Lunn RM, Langlois RG, Hsieh LL, Thompson CL, Bell DA. XRCC1 polymorphisms: effects on aflatoxin B1-DNA adducts and glycophorin A variant frequency. Cancer Res 1999;59: 2557-61

Madigan MP, Ziegler RG, Benichou J, Byrne C, Hoover RN. Proportion of breast cancer cases in the United States explained by well-established risk factors. J Natl Cancer Inst 1995;87:1681-5

Masson M, Niedergang C, Schreiber V, Muller S, Menissierde Murcia J, De Murcia G. XRCC1 is specifically associated with poly(ADP-Ribose) polymerase and negatively regulates its activity following DNA damage. Mol Cell Biol 1998;18: 3563-71

Mohrenweiser HW, Jones IM. Variation in DNA repair is a factor in cancer susceptibility: a paradigm for the promises and perils of individual and population risk estimation? Mutat Res 1998;400:15-24

Moullan N, Cox DG, Angele S, Romestaing P, Gerard JP, Hall J. Polymorphisms in the DNA repair gene XRCC1, breast cancer risk, and response to radiotherapy. Cancer Epidemiol Biomarkers Prev 2003;12:1168-74

Nash RA, Caldecott KW, Barnes DE, Lindahl T. XRCC1 protein interacts with one of two distinct forms of DNA ligase III. Biochemistry 1997;36:5207-11

Nelson HH, Kelsey KT, Mott LA, Karagas MR. The XRCC1 polymorphism, sunburn, and non-melanoma skin cancer: evidence of gene-environment interaction. Cancer Res 2002;62: 152-5

Ratnasinghe D, Yao SX, Tangrea JA, Qiao YL, Andersen MR, Barrett MJ, Giffen CA, Erozan Y, Tockman MS, Taylor
PR. Polymorphisms of the DNA repair gene XRCC1 and lung cancer risk. Cancer Epidemiol Biomarkers Prev 2001;10: $119-23$

Shen MR, Jones IM, Mohrenweiser HW. Nonconservative amino acid substitution variants exist at polymorphic frequency in DNA repair genes in healthy humans. Cancer Res 1998;58:604-8

Shu XO, Cai Q, Gao YT, Wen W, Jin F, Zheng W. A population-based case-control study of the Arg399GIn polymorphism in DNA repair gene XRCC1 and risk of breast cancer. Cancer Epidemiol Biomarkers Prev 2003;12:1462-7

Smith TR, Miller MS, Lohman K, Lange EM, Case LD, Mohrenweiser HW, Hu JJ. Polymorphisms of XRCC1 and XRCC3 genes and susceptibility to breast cancer. Cancer Lett 2003a;190:183-90

Smith TR, Levine EA, Perrier ND, Miller MS, Freimanis RI, Lohman K, Case LD, Xu J, Mohrenweiser HW, Hu JJ. DNA-repair genetic polymorphisms and breast cancer risk. Cancer Epidemiol Biomarkers Prev 2003b;12:1200-4

Stern M, Umbach M, van Gils CH, Lunn RM, Taylor JA. DNA repair gene XRCC1 polymorphisms, smoking, and bladder cancer risk. Cancer Epidemiol Biomarkers Prev 2001;10: 125-31

Vidal AE, Boiteux S, Hickson ID, Radicella JP. XRCC1 coordinates the initial and late stages of DNA basic site repair through protein-protein interactions. EMBO J 2001;20: $6530-9$

Yu Z, Chen J, Ford BN, Brackley ME, Glickman BW. Human DNA repair systems: an overview. Environ Mol Mutagen 1999;33:3-20 